\title{
First Historical Eruption of Kambalny Volcano
}

\author{
Academician E. I. Gordeev ${ }^{a}$, O. A. Girina ${ }^{a} * *$ N. V. Gorbach ${ }^{a}$, A. G. Manevich ${ }^{a}$, D. V. Melnikov ${ }^{a}$, \\ L. P. Anikin ${ }^{a}$, T. M. Manevich ${ }^{a}$, I. K. Dubrovskaya ${ }^{a}$, S. A. Chirkov ${ }^{a}$, and E. V. Kartashova ${ }^{a}$ \\ Received January 16, 2018
}

\begin{abstract}
The first historical eruption of Kambalny volcano began on March 24, 2017 with the powerful ash emission from the summit crater reaching as high as $6 \mathrm{~km}$ above sea level. The explosive activity continued without interruption from March 24 to March 30. The most powerful ash emission was registered on March 25-26, when the ash plume drifted several thousand kilometers SW, S, and SE from the volcano. On April 2 and April 9, after several calm days, powerful ash explosions occurred generating ash plumes up to $7 \mathrm{~km}$ high. The area of the land and sea over which the ash plume drifted during the day of March 25, was $650000 \mathrm{~km}^{2}$; the area of the ash accumulation on the land that was formed from March 24 to April 9, exceeded $1500 \mathrm{~km}^{2}$. These parameters were measured using the satellite-based data in the VolSatView information system. Domination of the silty fraction and the presence of secondary minerals (pyrite, gypsum, sulfur, and others) in the ash point to the phreatic character of the volcanic eruption.
\end{abstract}

DOI: $10.1134 / \mathrm{S} 1028334 \mathrm{X} 18100045$

Kambalny volcano $\left(2156 \mathrm{~m}, 51.18^{\circ} \mathrm{N}, 156.52^{\circ} \mathrm{E}\right)$ is the southernmost active volcano of Kamchatka. It closes the Kambalny Ridge from the south occupying the edge of the rockfall/glacier (?) cirque $5 \times 3.5 \mathrm{~km}$ in size [5]. The Kambalny ridge is composed of transformed volcanic rocks of Lower Pleistocene-Holocene age. The base of the volcano is composed of tuffpyroclastic and lava formations of the Late Pliocene and Lower and Middle Pleistocene stratovolcanoes [3]. The rocks of the Kambalny stratovolcano are represented by the series from basalts to andesitebasalts [6]. At the top of the volcano, there is a crater $0.8 \times 0.4 \mathrm{~km}$ in size and up to $150 \mathrm{~m}$ deep; on the southeastern summit part of the volcano, there is an explosion funnel $200 \times 100 \mathrm{~m}$ in size and $50 \mathrm{~m}$ depth; the southwestern slope of the volcano is covered by blanketlike light-color loose rocks of explosion-rockfall (?) origin. According to the data of tephrochronology, the first Holocene eruptions of the volcano occurred about 8000 and 7500 years ago; the last powerful eruptions occurred about 200 (?) and 600 years ago $[5,6]$. There are no reliable data on historical eruptions of the volcano.

The staff members of the South Kamchatka Federal Sanctuary keep watch over Kambalny volcano. Since 2002 daily satellite-based monitoring of the volcano has been conducted by the Kamchatka Volcanic

anstitute Volcanology and Seismology, Far East Branch, Russian Academy of Sciences, Petropavlovsk-Kamchatsky, 683006 Russia

*e-mail: girina@kscnet.ru
Eruption Response Team (KVERT) [1], and since 2014 monitoring has been carried out using the VolSatView information system for Monitoring of Volcanic Activity in Kamchatka and on the Kuril Islands [2]. According to the satellite-based monitoring of the volcano, in the years 2002-2017, no thermal anomaly in the area of the volcano was registered (until the beginning of the eruption).

On the morning of March 25, the scientists of KVERT received a message from G. Volynts from Utashud Island (Vestnik Bay in southeastern Kamchatka) about the eruption of Kambalny volcano. Analysis of the Himawari-8 satellite images in the VolSatView information system allowed us to determine the time when the eruption of Kambalny volcano started; it was at 21:10 UTC on March 24. At first, the ash plume, increasingly loaded with ash particles, drifted SW from the volcano (azimuth $235^{\circ}$ ) (Fig. 1), but gradually turned S and SE. Explosive activity continued without interruption from March 24 to March 30 . The most powerful ash emission was registered on March 25-26; one day after the volcanic activity, the front part of the plume, saturated by ash particles, $290 \times 105 \mathrm{~km}$ in size was at a distance of $904 \mathrm{~km}$ (azimuth $169^{\circ}$ ) from the volcano. The area of the land and sea over which the ash plume drifted during this day was about $650000 \mathrm{~km}^{2}$.

On April 2, at 18:40 UTC, after two days of relative calm, a powerful emission of ash occurred reaching up to $7 \mathrm{~km}$ high above sea level. The steam-gas activity of the volcano with the emission of various amounts of ash continued from April 2 to April 5. On April 9, at 06:30 UTC, after a calm period, the explosions again 


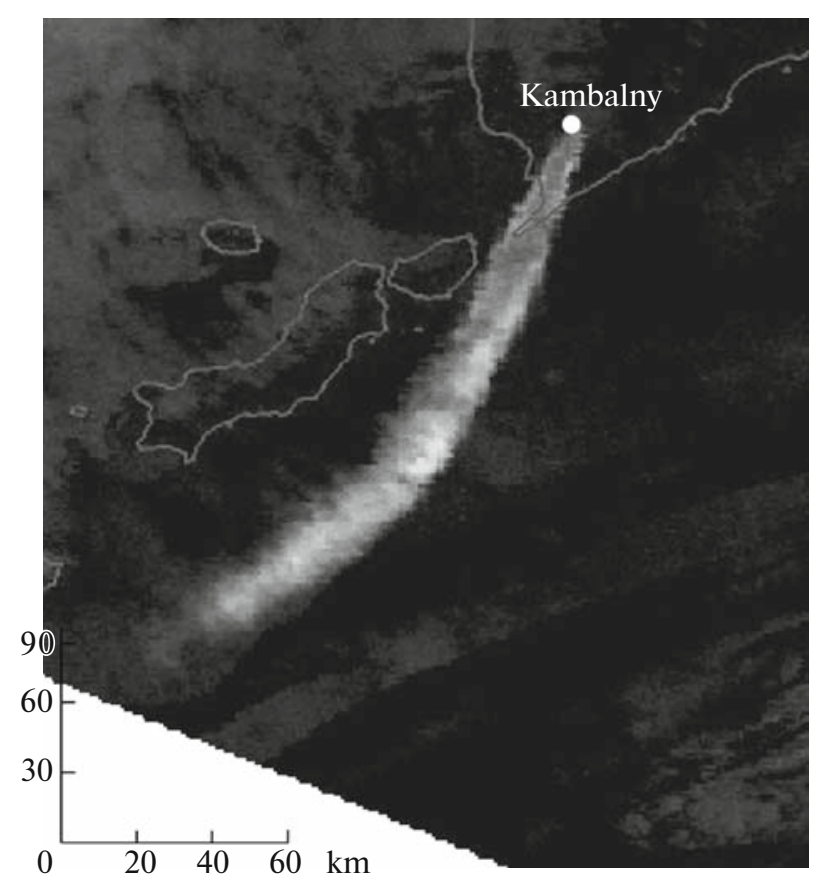

Fig. 1. The ash plume from the Kambalny volcano as of March 25, 2017, on the NOAA 19 satellite image made at 04:09 UTC. The data were obtained from the VolSatView information system [2].

raised ash up to $7 \mathrm{~km}$ above sea level; the ash plume drifted NE from the volcano; on April 10 the direction changed to the SE. Later on, only moderate fumarole activity of Kambalny volcano was registered, sometimes (April 19) with the emission of a small amount of ash. The total area of the ash accumulation on the land, measured by the satellite-based data in the VolSatView information system, exceeds $1500 \mathrm{~km}^{2}$.

On April 12, 2017, using a helicopter of the Ministry of Emergency Situations that circled over the volcano, ash was sampled and thermal survey of the volcano summit was made. This allowed us to clarify the type of the first historical eruption of Kambalny volcano. The eruptive column was initially inclined by $45^{\circ}$ to the horizon, and ash was emitted from the southwestern part of the crater (Fig. 2). In the observation of the volcano summit, it was revealed that the eruptive activity was attributed to the fissure zone stretching from a large funnel on the slope along the

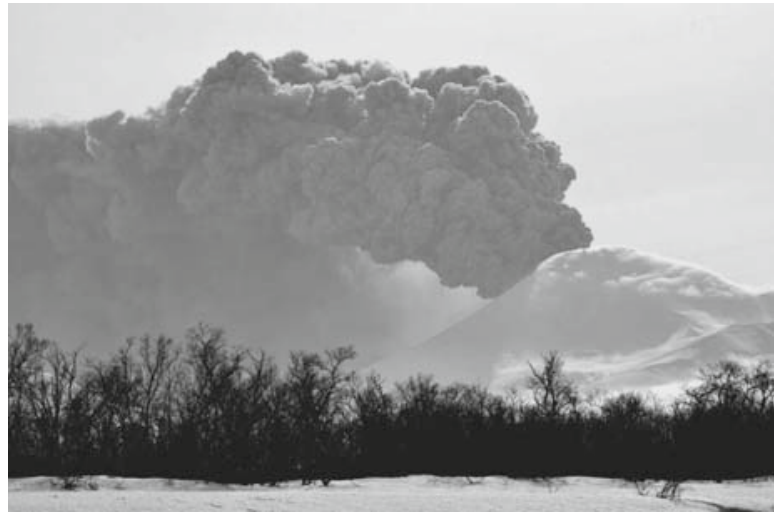

Fig. 2. Eruption of Kambalny volcano on March 25, 2017. Photo by L. Varavskaya.

western flank of the crater. The fissure zone is defined by several large uneven openings inside the flank and at the crater outlet, from which the powerful gas emission occurred during the observation, as well as by the vertically elongated fissures on the northern flank of the funnel in the summit part of the volcano slope (Fig. 3). The main volcanic funnel about $100 \mathrm{~m}$ in diameter, from which, probably, the main mass of ash was emitted, is located at the outlet from the crater bordering the western flank of the crater. According to the infrared survey of the crater as of April 12, 2017, the temperatures of the steam-gas mixture in the fumarole mouth was $50^{\circ} \mathrm{C}$; the heating of the rocks composing the local zone of the crater outlet was $26^{\circ} \mathrm{C}$.

In the southern zone of the ashfalls, the branches of cedar elfin wood above the snow cover had a yellow color resulting, probably, from high ash acidity. In the zone of heavy ashfalls, mud streams flowed along the rivers, clear from ice; the rivers brought ashes into Kurilskoye Lake.

The products of the eruption were sampled $9 \mathrm{~km}$ and $20 \mathrm{~km}$ away from the volcano. At a distance of $9 \mathrm{~km}$ from the volcano, the ash mass ranged from 1.5 to $2 \mathrm{~kg} / \mathrm{m}^{2}$. According to the particle size composition, the ashes (at both sampling places) are silty sands with the following percentage of particles: $<0.064 \mathrm{~mm}$ in size $58-64 \%$; $0.064-0.125 \mathrm{~mm}$ in size $11-16 \%$, $0.125-0.25 \mathrm{~mm}$ in size $19-23 \%,>0.25 \mathrm{~mm}$ in size from 1 to $8 \%$. The chemical composition of the ashes corresponds to andesites $\left(\mathrm{SiO}_{2}=58.8-60.2 \mathrm{wt} \%\right)$

Table 1. The chemical composition of the ash of the Kambalny volcanic eruption in 2017, wt \%

\begin{tabular}{c|c|c|c|c|c|c|c|c|c|c|c|c|c|c}
\hline no. & $\mathrm{SiO}_{2}$ & $\mathrm{TiO}_{2}$ & $\mathrm{Al}_{2} \mathrm{O}_{3}$ & $\mathrm{Fe}_{2} \mathrm{O}_{3}$ & $\mathrm{FeO}$ & $\mathrm{MnO}$ & $\mathrm{MgO}$ & $\mathrm{CaO}$ & $\mathrm{Na}_{2} \mathrm{O}$ & $\mathrm{K}_{2} \mathrm{O}$ & $\mathrm{P}_{2} \mathrm{O}_{5}$ & LOI & $\mathrm{S}$ & Total \\
\hline 1 & 60.2 & 0.69 & 18.2 & 2.8 & 2.57 & 0.1 & 2.44 & 5.2 & 2.99 & 1.06 & 0.17 & 3.22 & 0.65 & 99.63 \\
2 & 58.8 & 0.76 & 17.8 & 2.32 & 4.14 & 0.14 & 3.06 & 6.62 & 3.38 & 1.04 & 0.15 & 1.41 & 0.28 & 99.64 \\
\hline
\end{tabular}

Ashes were sampled: (1) $9 \mathrm{~km}$ and (2) $20 \mathrm{~km}$ from the volcano on April 12, 2017. Analyses were conducted by N.Yu. Kurnosova, V.M. Ragulina, and N.M. Chebrova in the Analytical Center of the Institute Volcanology and Seismology, Far East Branch, Russian Academy of Sciences. 


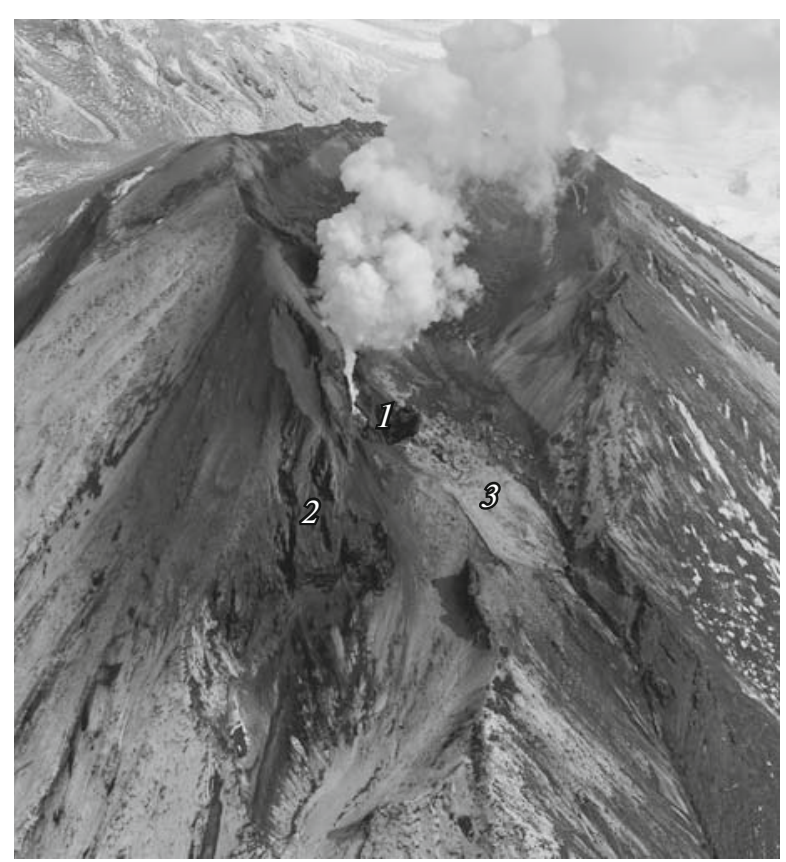

Fig. 3. The summit of Kambalny volcano on April 12, 2017. (1) Main funnel from which the main ash emitted; (2) vertically elongated fissures on the northern flank of the funnel on the slope of the volcano; (3) the zone of heated rocks at the outlet of the crater. Photo by A. Sokorenko.

with a moderate $\mathrm{K}$ content $\left(\mathrm{K}_{2} \mathrm{O}=1.04-1.06 \mathrm{wt} \%\right)$ and an increase in the $\mathrm{S}$ content (from 0.3 to $0.6 \mathrm{wt} \%$ ) (Table 1). Analysis of the particles under a binocular microscope and with the use of the SEM Vega-3 Teskan scanning electron microscope (Institute of Volcanology and Seismology, Far East Branch, Russian Academy of Sciences) revealed crystals of pyrite, particles of native sulfur, pyrrhotine, quartz, barite, gypsum, opal, and scattered signs of colorless zircon and apatite along with rock-forming minerals (plagioclase, ortho, and clinopyroxene, olivine, hornblende, and magnetite). On the basis of the above data, we can confidently speak about the resurgent composition of the ashes and, consequently, about the phreatic character of the explosive eruption of the volcano.

According to [4], there are several reasons for phreatic eruptions (when a definite volume of hot ground water immediately turns into steam of high pressure): a gradual increase in the temperature due to magma upwelling; the immediate overheating of the water steam that was enclosed in the initially impermeable highly heated rocks of the waterproof bed, in newly formed open fissures in the rocks; the water overheating due to the newly formed deep faults along which the deep, high temperature waters could move upward and mix with the waters of the water-bearing horizon; the sudden drop of lithohydrostatic pressure because of the opening of the fissures above the water-bearing horizon.

To clarify the reasons for the phreatic eruption of Kambalny volcano, additional studies are necessary.

The further activity of the volcano can go according to several scenarios. If the phreatic character of the volcano eruption continues unchanged, discrete explosions up to 7-10 km above sea level are possible. In the magma upwelling to the surface, the transition to phreatic-magmatic and magmatic types of volcanic activity with ash explosions, lava outflow, or formation of a lava dome is possible. The data on the Holocene activity of the volcano [4, 5] do not exclude the partial destruction of the volcanic edifice during explosions with the formation of rockfall sediments.

\section{ACKNOWLEDGMENTS}

This work was supported by the Russian Science Foundation, project no. 16-17-00042.

\section{REFERENCES}

1. E. I. Gordeev and O. A. Girina, Herald Russ. Acad. Sci. 84 (1), 1-8 (2014). doi 10.1134/S1019331614010079

2. E. I. Gordeev, O. A. Girina, E. A. Lupyan, et al., J. Volcanol. Seismol. 10 (6), 382-394 (2016). doi 10.1134/S074204631606004X

3. N. E. Litasov and A. A. Vazheevskaya, in Active Volcanoes of Kamchatka (Nauka, Moscow, 1991), Vol. 2, pp. 396-405 [in Russian].

4. G. Taziev, in Problems of Deep Volcanism (Nauka, Moscow, 1979), pp. 70-75 [in Russian].

5. V. V. Ponomareva, T. Churikova, I. V. Melekestsev, et al., in Volcanism and Subduction: The Kamchatka Region (Am. Geophys. Union, Washington, DC, 2007), Vol. 172, pp. 165-198. doi 10.1029/172GM15

6. V. V. Ponomareva, I. V. Melekestsev, and O. V. Dirksen, J. Volcanol. Geotherm. Res. 158 (1-2), 117-138 (2006). doi 10.1016/j.jvolgeores.2006.04.016

Translated by V. Krutikova 